лімфогенне метастазування - 36,7\%, віддалене метастазування в легені - 5,2\%). 3 часом підвищення якості ультразвукової і цитологічної діагностики дозволило збільшити кількість операцій, які проведені на ранніх стадіях розвитку карцином - до 59,8\% спостережень. В терапевтичному протоколі була використана тактика рестратифікації ризику на етапах лікування, з визначенням обсягу хірургічного втручання, характеру терапії радіоактивним йодом і супресивної терапії левотироксином.

Проведено 5267 (90,3\%) тиреоїдектомій, 563 (9,7\%) лобектомій при мінімально-інвазивній папілярній карциномі, 1633 (29\%) дисекцій шиї різного обсягу. При локально-інвазивних пухлинах виконувались операції 3 резекцією органів аеродигестивного тракту. В більшості випадків при розповсюджених формах захворювання виконання тиреоїдектомії 3 дисекцією центрального та, при необхідності, бокових відсіків шиї 3 подальшою аблацією радіоактивним йодом дозволило знизити кількість рецидивів в 2,5 рази. Рецидивні та резидуальні йодрезистентні метастази призвели до повторних операцій. Виконання профілактичної дисекції центрального відсіку шиї дозволило покращити

Дата надходження до редакції 09.10.2018р. діагностику мікрометастазів, досягти зниження рівня передаблаційного тиреоглобуліну та знизити променевенавантаженняпритерапіїl131.Виконання лобектомії при мінімально-інвазивній папілярній карциномі категорії Т1 $\epsilon$ досить радикальним втручанням і не збільшує ризик розвитку рецидиву. Застосування диференційованого лікувального підходу дозволило досягти сприятливих результатів лікування. Безрецидивна виживаність протягом 5 років становила 95,7\%, 10 років - 92,5\% і 15 років - 79,4\%. Кумулятивне п'ятирічне виживання за методом Каплан-Мейер становило 99,1\%, десятирічне - 98,9\%, п'ятнадцятирічне - 98,9\%.

Висновки. Стратегії лікування папілярних тиреоїдних карцином у населення України мають носити персоніфікований характер. В більшості випадків залишається виправданим радикальний протокол лікування, який оснований на виконанні тиреоїдектомії 3 дисекцією шиї та аблаційною терапією 1131. В групі низького ризику при мінімально-інвазивній папілярній карциномі можливе виконання гемітиреоїдектомії з наступною супресивною терапією левотироксином.

\title{
ІНФАРКТ МІОКАРДУ ТА ІНСУЛЬТ У ХВОРИХ НА ЦУКРОВИЙ ДІАБЕТ 2 ТИПУ: ЕПІДЕМІОЛОГІЧНІ ТА СОЦІАЛЬНО-ЕКОНОМІЧНІ АСПЕКТИ
}

\author{
3.Г. Крушинська \\ Украйнський науково-практичний иентр ендокринної хірургії, трансплантації \\ ендокринних органів і тканин МОЗ України
}

Мета: Вивчити епідеміологічні та соціальноекономічні особливості інфаркту міокарду (IM) та інсульту у хворих на цукровий діабет (ЦД) 2 типу.

Матеріали та методи. Пацієнти були розподілені на 3 групи: до першої групи увійшли всі хворі на ЦД, які взяли участь у дослідженні ( $n=1999)$, до другої групи - хворі на ЦД з першої групи з IM $(n=201)$, до третьої групи - хворі на ЦД з першої групи з інсультом ( $n=155)$. Кожна група також була розподілена з урахуванням статі хворого.

Особливості перебігу IM та інсульту у хворих на ЦД (вік, стать, соціальний статус, місце проживання, тривалість захворювання, рівень глікованого гемоглобіну, частота ускладнень та супутньої патології, наявність ожиріння, схеми лікування) i взаємозв'язок між ними вивчалися з використанням порівняльного аналізу отриманих даних.

Результати. У першій групі частка хворих обох статей практично не відрізняється, у другій групі більшість становлять чоловіки (55,7\%), у третій групі - жінки (58,1\%). Аналогічна ситуація спостерігається також при дослідженні частоти IM та інсульту у хворих на ЦД в залежності від статі пацієнта: серед хворих на ЦД з ІМ переважають чоловіки (10,9 проти 
9,1\% у жінок), з інсультом - жінки (9,2 проти 6,4\%).

Середній вік пацієнтів першої групи на час дослідження становив 59,4 року проти 64,7 року В другій групі та 62,4 року в третій групі хворих. Не зареєстровано жодного пацієнта віком до 40 років у другій та третій групах, а мінімальний вік у першій групі більш ніж удвічі нижчий за аналогічний показник у другій та третій групах (20 років проти 43-48 років).

Частка пацієнтів з соціально незахищених верств населення у першій групі становить 71,4\%, у другій та третій групах цей показник перевищує $80 \%$ $(81,1$ та $82,6 \%$ відповідно), найвище у жінок по всіх трьох групах $(81,2 ; 86,5$ та 87,8\% відповідно). Більшість хворих по всіх трьох групах проживає у містах-мегаполісах $(60,8 \%)$, а також у депресивних у соціально-економічному плані регіонах $(21,8 \%)$ та на підконтрольній території окупованих регіонів (4,9\%). Повторний IM було зареєстровано у $3 \%$ хворих на ЦД, особливо у жінок (3,4\% проти 2,7\% у чоловіків). Більш ніж утричі частіше за повторний IM траплявся повторний інсульт $(9,7 \%)$, удвічі частіше у жінок (12,2\% проти 6,2\% у чоловіків). Частка хворих на IM серед хворих на інсульт удвічі вища за аналогічний показник серед усіх хворих на ЦД $(20,7$ та $10,1 \%$ відповідно), насамперед за рахунок чоловіків (33,9 проти $10,9 \%$ серед усіх пацієнтів), частота IМ у жінок третьої групи незначно більше за такий показник по першій групі - 11,1 та 9,1\% відповідно. Частка хворих на інсульт серед пацієнтів з ЦД та ІМ удвічі більше за аналогічний показник серед усіх хворих на ЦД (15,5 проти 7,8\% відповідно), утричі частіше у чоловіків (17,9 проти 6,4\% відповідно), незначно більше у жінок (12,5 та 9,2\% відповідно). Середній рівень глікованого гемоглобіну по всіх трьох групах фактично на одному рівні (у першій групі - 9,0, другій групі - 9,1, третій групі - 8,9) та відповідає декомпенсації ЦД, найбільше у жінок по трьох групах (9,2; 9,3 та 9,1 відповідно).

Висновки. Встановлено суттєві відмінності між частотою ЦД і частотою IM та інсульту у цих хворих залежно від статі пацієнта. Середній вік хворих на ЦД з ІМ та інсультом та середня тривалість захворювання на ЦД вищі порівняно з загальною популяцією хворих на ЦД. Переважну більшість становлять соціально-незахищені верстви населення. Повторні захворювання на IM та інсульт у хворих на ЦД частіше у жінок. Частота перехресних захворювань (ІМ у хворих на ЦД та інсульт, інсульт у хворих на ЦД та IM) удвічі перевищує показники частоти IM та інсульту серед хворих на ЦД, втричі частіше у чоловіків.

Ключові слова: цукровий діабет, інсульт, інфаркт, особливості перебігу.

\section{ЛITЕРАТУРА}

1. International Diabetes Federation. IDF Diabetes Atlas, 8th ed. Brussels: IDF, 2017.

2. Introduction: Standards of Medical Care in Diabetes - 2018. Diabetes Care. 2018; 41(Suppl. 1):S1-S2. doi: $10.2337 / \mathrm{dc} 18-$ Sint01.

3. Zheng Y, Ley $S H, H u F B$. Global aetiology and epidemiology of type 2 diabetes mellitus and its complications. Nat Rev Endocrinol. 2018 Feb;14(2):88-98. doi: 10.1038/nrendo.2017.151.

Дата надходження до редакції 23.10.2018 p.

https://doi.org/10.24026/1818-1384.4(64).2018.150178

\title{
АНАЛІЗ 22-РІЧНОГО ДОСВІТУ ХІРУРГІЧНОГО ЛІКУВАННЯ ПУХЛИН НАДНИРКОВИХ ЗАЛОЗ В УМОВАХ СПЕЦІАЛЗОВАНОГО ЕНДОКРИНОЛОГІЧНОГО ЦЕНТРУ
}

\author{
М.В. Кунатовський, О.А. Товкай, С.О. Тарасенко, О.О. Сфімова \\ Украйнський науково-практичний иентр ендокринної хірургії, трансплантаиї \\ ендокринних органів і тканин МОЗ України
}

Вступ. Хірургія надниркових залоз (Н3) завжди вважалася одним із найбільш ризикованих і технічно складних втручань через поєднання особливих топографо-анатомічних умов, необхідності виконання великого й травматичного операційного доступу незалежно від його виду (лапаротомічного, люмботомічного, торако-люмботомічного), власної структури органа, наявності у багатьох пацієнтів ендокринних системних змін, що створюють додаткові перешкоди. Розвиток нових хірургічних 